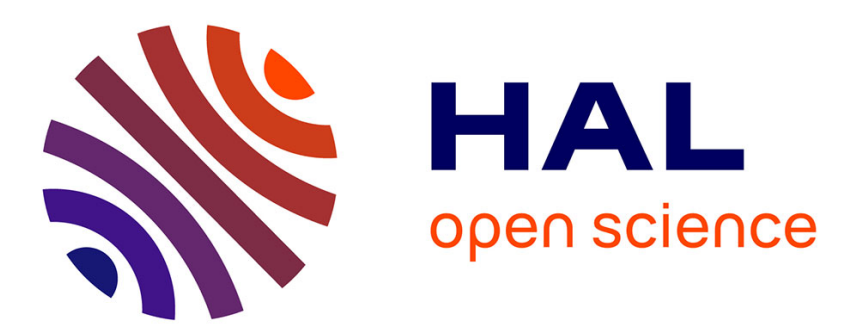

\title{
Experimental evidence for crustal control over seismic fault segmentation
}

\author{
M. Lefevre, P. Souloumiac, N. Cubas, Y. Klinger
}

\section{To cite this version:}

M. Lefevre, P. Souloumiac, N. Cubas, Y. Klinger. Experimental evidence for crustal control over seismic fault segmentation. Geology, 2020, 48 (8), pp.844-848. 10.1130/G47115.1 . hal-03063897

\section{HAL Id: hal-03063897 \\ https://hal.science/hal-03063897}

Submitted on 14 Dec 2020

HAL is a multi-disciplinary open access archive for the deposit and dissemination of scientific research documents, whether they are published or not. The documents may come from teaching and research institutions in France or abroad, or from public or private research centers.
L'archive ouverte pluridisciplinaire HAL, est destinée au dépôt et à la diffusion de documents scientifiques de niveau recherche, publiés ou non, émanant des établissements d'enseignement et de recherche français ou étrangers, des laboratoires publics ou privés. 
1 Experimental evidence for crustal control over seismic fault

2 segmentation

3

4 Lefevre $^{1^{*}}$ M., Souloumiac ${ }^{2}$ P., Cubas $^{3}$ N., $^{-}$Klinger $^{1^{*}}$ Y.

5

6 1: Université de Paris, Institut de physique du globe de Paris, CNRS, F-75005 Paris,

7 France

8 2: GEC, Université de Cergy-Pontoise, F-95000 Neuville sur Oise, France

9 3: Sorbonne Université, ISTEP, F-75005 Paris, France

10 marthe.lefevre1@gmail.com

ABSTRACT

13 Strike-slip faults are described as continuous structures, while they are actually

14 formed of successive segments separated by geometrical complexities. Although

15 this along-strike segmentation is known to affect the overall dynamics of 16 earthquakes, the physical processes governing the scale of this segmentation 17 remain unclear. Here, we use analogue models to investigate the structural 18 development of strike-slip faults and the physical parameters controlling 19 segmentation. We show that length of fault segments is regular along strike, and 20 scales linearly with the thickness of the brittle material. Variations of the 21 rheological properties only have minor effects on the scaling relationship. Ratios

22 between the segment length and the brittle material thickness are similar for co-

23 seismic ruptures and sandbox experiments. This supports a model where crustal 24 seismogenic thickness controls fault geometry. Finally, we show that the 
geometrical complexity acquired during the strike-slip fault formation withstands cumulative displacement. Thus, inherited complexity impedes the formation of an ever straighter fault, and might control the length of earthquakes ruptures.

\section{INTRODUCTION}

Strike-slip faults are discontinuous features formed by a succession of segments, separated by geometrical complexities, such as bends, or relay zones (Fig. 1.a, S1)(e.g. Segall and Pollard, 1980). Although the size of these complexities is highly variable, even the smaller ones can significantly affect initiation, propagation, and termination of earthquakes (e.g. King and Nabelek, 1985; Wesnousky, 2006; Klinger et al., 2005; Manighetti et al., 2007), implying their persistence at seismogenic depth (e.g. Schwartz and Coppersmith, 1984; Wei et al., 2011; Schwartz, 2018). Fault discontinuities also modulate amplitude and style of co-seismic surface deformation (Klinger et al., 2006; Vallée et al., 2008), and might stop ruptures propagation if larger than $5 \mathrm{~km}$ (e.g. Wesnousky, 2006). Recently, numerical simulations of rupture scenarios have confirmed the strong dependency of earthquake rupture models on the geometry of the fault system (e.g. Aochi and Ulrich, 2015; Lozos, 2016; Klinger et al., 2018). As a consequence, understanding the genesis of the segmentation and its scaling is critical for physicsbased earthquake modeling, as well as for hazard assessment, since complexities impact the earthquake rupture length, and thus its magnitude.

Based on experimental, seismological, and geomorphological studies, fault segmentation was first described as fractal (e.g. Aviles et al., 1987; Okubo and Aki, 1987). Alternatively, it was suggested that faults are composed of a fixed number of segments, implying a segment length varying between faults (e.g. Manighetti et al., 2015). 
Conversely, studies based on co-seismic rupture maps have argued in favor of a constant segment length of about $18 \mathrm{~km} \pm 5 \mathrm{~km}$, independent of the regional tectonic setting or the earthquake magnitude, suggesting an external controlling factor, which is assumed to be the seismogenic crust thickness (e.g. Bilham and Williams, 1985; Klinger, 2010)(Fig. 1.a). However, detailed co-seismic rupture maps are available only for a limited number of earthquakes, preventing a reliable statistical analysis. The lack of data combined with our limited knowledge of the fault segmentation process prevent us from discriminating between these models.

To tackle the origin of strike-slip fault segmentation, we followed an analogue modeling approach, which provides the complete geometrical evolution of the fault structure while accumulating slip. Moreover, a large number of experiments can be conducted, allowing for a thorough exploration of the impact of the geometrical and rheological parameters.

\section{ANALOGUE MODELING OF STRIKE-SLIP FAULTS}

Numerous analogue studies already focused on the formation and final geometry of strike-slip faults systems (Dooley and Schreurs, 2012 and references therein). In experiments with sand overlying a straight basal dislocation, the first structures to appear are the Riedel shears (R-shears)(Riedel, 1929; Naylor et al., 1986), propagating upward (e.g. Ueta et al., 2000, Cambonie et al., 2018), oriented at the surface at an angle of $\varphi_{\text {int }} / 2$ relative to strike-slip basal fault ( $\varphi_{\text {int, }}$ angle of internal friction of the material). This orientation is due to the helicoidal shape of the Riedels (Fig 1,b) (Naylor et al., 1986; Mandl, 1987). The next structures to appear are first, synthetic shears (S-shear) that only slightly deviate from the strike of the basal fault, and finally P-shears, which cross the basal fault in the opposite direction. Eventually, coalescence of these different 
shears leads to the formation of an anastomosed fault zone (e.g. Naylor et al., 1986; Richard et al., 1995).

Here, we investigate if the first structures to appear during the formation of strike-slip faults can be responsible for the long-term segmentation. As these faults result from the linkage of the S-shears, the initial discontinuities between them at the locations of the Riedels might persist and give rise to geometrical complexities. Therefore, we consider the distance between two adjacent Riedels as equivalent to a fault segment. Although dependency of the length of Riedels on the thickness of the frictional material had already been suspected, it was never indisputably demonstrated (Tchalenko, 1970; Atmaoui et al., 2006, Hatem et al., 2017). Thus, we first evaluate the influence of the material thickness on the inter-Riedels distance, and then the impact of intrinsic properties of the material.

We used an analogue model set-up known as Riedel experiments in a $1.2 \mathrm{~m}$ x $0.8 \mathrm{~m}$ box (detailed set-up in Supp. Mat., Fig. S2). The model reproduces brittle deformation in a non-cohesive material during the onset of a strike-slip fault in a homogeneous sandpack above a straight-basal fault. To test the impact of the frictional properties on the fault geometry, we used four different Aeolian sands with different internal frictions (Sand 1, $\varphi_{\text {int }}=43.7^{\circ}$; Sand 2, $\varphi_{\text {int }}=35.6^{\circ}$; Sand 3, $\varphi_{\text {int }}=33.4^{\circ}$; Sand $\left.4, \varphi_{\text {int }}=22.1^{\circ}\right)$ and variable basal materials, such as PVC $\left(\varphi_{b}=13^{\circ}\right)$ Alkor-foil $\left(\varphi_{b}=18^{\circ}\right)$ and sand paper $\left(\varphi_{b}>43,7^{\circ}\right)$. Some of these sands are poured and have a rate-hardening behavior (sand 2, 3 and 4), while sand 1 is sedimented and rate-weakening (see Supp. Mat. for material properties). A camera placed above the box records the deformation every $0.5 \mathrm{~mm}$ of basal displacement to generate orthoimages of the sandbox surface, with a resolution of the order of the grain size. Moreover, to assess how the shear is accommodated by the different structures, we computed the incremental displacement field from optical images correlation using 
111 S4).

Micmac software (Rosu et al., 2015). The set-up is intentionally simple to limit the number of free parameters and to ensure a good control on the boundary conditions of the experiment. The aim of these experiments is not to reproduce details of a realistic strike-slip fault evolution, but to retrieve relationships between fault-characteristic patterns and properties of material.

For each sandpack thickness (T), three parameters were extracted from surface images for each Riedel: the inter-Riedel distances (S) measured parallel to the trace of the basal fault, the Riedels length (L), and the angle ( $\alpha$ ) formed by the Riedel with the direction of the basal fault (Fig. 1.c). We ran repeated experiments with thicknesses varying from 2 to $5 \mathrm{~cm}$ (Table S1). Only the experiments with thicknesses lower or equal to $5 \mathrm{~cm}$ were free of edge effects (Fig. S3). The minimum thickness is constrained by the ability of the sand to develop the 3D helicoidal shape of Riedel shears. When sand is thinner than 1.5 $\mathrm{cm}$, instead of the Riedel shears, a continuous fault directly appears at the surface (Fig.

112 To provide robust correlations between thickness, material properties, and fault

113 geometry, we need repeated experimental measurements. As several Riedels are visible 114 in each experiment, we checked that we could use them as independent measurements 115 to improve statistical significance (see verification in Supp. Mat.). In the following, for 116 clarity's sake, only average quantities per experiment are presented and discussed 117 (individual measurements in Supp. Mat. Fig. S7-S11).

\section{SCALING RELATIONSHIPS DERIVED FROM SANDBOX}

119 Surface images of the experiments for different thicknesses (T) show that the deformed 120 area widens and the inter-Riedel distance (S) increases for thicker sandpack (Fig. 2.a). 
121 Indeed, systematic measurements of (S) for different (T) show a linear correlation 122 between those parameters (Fig. 2.b), with a scale factor of about 2.8 for Sand 1.

123 To test the potential effect of the material properties, we first performed experiments 124 with sands of different internal friction. The three sets of experiments exhibit the same 125 trend: (S) increases with (T)(Fig. 2.c, S7), and the measurements distributions are well 126 modeled by linear relationships. Nevertheless, depending on the internal friction, the 127 slope of the best-fit lines changes, indicating a partial control of the material properties 128 on the size of the structures. The slope is 1.43 for the smaller friction $\left(\phi_{\mathrm{int}}=33.4^{\circ}\right.$, Sand $1293), 1,61$ for the intermediate friction $\left(\phi_{\mathrm{int}}=35.6^{\circ}\right.$, Sand 2$)$, and 2.76 for the highest one 130 ( $\phi_{\text {int }}=43.7^{\circ}$, Sand 1$)$. As Sand 2 and 3 present relatively similar relationships (Fig. 2.c) 131 and are both strain-hardening, we cannot exclude from our data that the discrepancy 132 between Sand 1 and other sands could be due to its strain-weakening properties instead 133 of its internal friction (Fig. S11). Nevertheless, as Riedel shears form when shear stress 134 reaches the static friction (Tchalencko, 1970, Ritter et al. 2018), we think that the 135 internal friction, of the sands controls the relation between $\mathrm{S}$ and $\mathrm{T}$, and not its strain 136 hardening or weakening property.

137 Using different materials to test the impact of the internal friction might also change the 138 basal friction between the different experiments. To assess a possible trade-off between 139 these two parameters, we conducted three series of experiments using Sand 1 with 140 different basal materials (Fig. 2.d, S7). For the three tested basal frictions we observed 141 linear relations between (S) and (T). The slopes of the regressions are quite similar, and 142 only the intercepts change slightly (Fig. 2.d). The associated change of x-axis intercept 143 corresponds to the minimal thickness necessary to develop the Riedels-helicoid. This 144 observation suggests that the basal friction impacts the formation of the helicoid, 
145

probably by changing the width of the deformed area at depth (see Supp. Mat. mechanical implications).

We then examined the effect of the cohesion on the inter-Riedel distance (S), using noncohesive (Sand 3) and strongly cohesive (Sand 4) sands (Fig. 2.e, S8). Again, (S) increases linearly with (T). The two linear regressions present the same slope but shifted intercepts, with a larger value for the highly cohesive sand (of about $1.5 \mathrm{~cm}$ ). However, this difference may not be significant in view of the small number of experiments associated to a high dispersion of the Sand 4 measurements, interpreted as resulting from heterogeneities in the sand mixture due to its electro-static charge (see Supp. Mat.). We consider that cohesion only marginally affects the fault geometry, as (S) is only slightly affected whereas all parameters vary and uncertainties are significant.

\section{COMPARISON OF EXPERIMENTAL RESULTS WITH EARTHQUAKE SURFACE-}

\section{RUPTURES GEOMETRY}

This new set of experiments demonstrates unambiguously that the inter-Riedel distance (S) is directly controlled by the thickness of the sandpack (T)(Fig. 2), while the material properties have secondary effects. The internal friction controls the scaling factor of the linear relation between (S) and (T), whereas the basal friction and the cohesion only marginally impact this relation. The width and rheology of the basal deformation zone, which are not addressed here, might also affect the size of structures (Hatem et al. 2017, Zuza et al. 2017, Yang et al. 2020).

According to field studies, strike-slip fault segments, measured between two successive relay zones, have similar lengths independently of the local tectonic setting (Klinger, 2010). Thus, it was suggested that the average length of fault segments scales with the thickness of the seismogenic crust (Bilham and Williams, 1985; Klinger, 2010), with a 
ratio close to 1 . To compare our experiments with natural observations, we selected sands 2 and 3, both non-dilatant and with frictions within the same range as standard

171 upper crust materials ( $\mu \sim 0.7)($ e.g. Byerlee, 1978).

172 For comparison, the inter-Riedel distance and the length of fault segments were 173 normalized respectively by the thickness of sand and of seismogenic crust, which is 174 derived from the literature (details in Supp. Mat.). The average normalized length for 175 natural fault segments is 1.16, and for sands 2 and 3 it is 1.17 and 1.3, which are 176 indistinguishable from the natural case (Fig. 3). Moreover, individual ratio values are all 177 in a narrow range $(\sigma=0.43)$, which indicates that such similarity is not coincidental. This 178 supports the hypothesis that the length of continental strike-slip segments is directly 179 controlled by the thickness of the seismogenic crust.

180 Although this approach does not capture the effects of a dynamic rupture, it sheds light 181 upon the way faults sections grow to eventually coalesce into an apparent continuous 182 structure. Interestingly, our experiments show that even when the cumulative 183 displacement during the experiment starts to be large enough to dismantle the Riedels 184 and to allow coalescence of successive S-shears into a longer fault, the initial geometric 185 discontinuity related to the location of the Riedel is preserved (Fig. 4.a). Riedels act as 186 inherited faults influencing the location of subsequent deformation. In the case of strike187 slip faults, such discontinuities will turn into relay zones, either compressional or 188 extensional. Indeed, in nature faults form in crust that already went through multiple 189 stages of deformation and that displays local geological variation. Thus the simple 190 scenario of faults structured only according to the thickness of the brittle crust is likely 191 modulated by inherited crustal heterogeneities, resulting in some relay zones being 192 larger than others. Sandbox experiments can also present such variability with larger 193 complexities randomly appearing (Fig. S14), suggesting that the initial orientation of the 
S-shears might also influence the size of the relay zones. Other studies have proposed that the off-fault deformation of earthquakes could be related to the reactivation of these Riedels (Hatem et al. 2017), although we could not observe such reactivation in our experiments. Moreover, in nature evidence of the initial Riedels structures is tenuous, as they accommodate a very short amount of deformation before being passively offset by the main active fault, which explains their weak morphological expression at the surface.

These results show that the first stages of deformation determine the long-term scaling

201 of the of strike-slip faults segmentation: Riedels create a regular pattern of geometrical complexities, which is inherited throughout the fault history (Fig. 4.b). This pattern of segmentation does not seem to experience significant changes even after the Riedels have ceased to be active, as we keep seeing it on the coseismic-rupture map. Thus, this 205 questions the paradigm that faults become even more linear while accumulating displacement through time, and thus prone to larger earthquakes. Instead, strike-slip fault geometry may retain a constant level of complexity, which controls the size of earthquakes.

\section{REFERENCES}

211 Aochi, H., and Ulrich, T., 2015, A probable earthquake scenario near Istanbul determined 212 from dynamic simulations: Bulletin of the Seismological Society of America, v. 105, no. 3, 213 p. 1468-1475, doi: 10.1785/0120140283>.

214 Atmaoui, N., Kukowski, N., Stöckhert, B., and König, D., 2006, Initiation and development 215 of pull-apart basins with Riedel shear mechanism: insights from scaled clay 216 experiments: International Journal of Earth Sciences, v. 95, no. 2, p. 225-238, doi: $217 \quad 10.1007 /$ s00531-005-0030-1.

218 Aviles, C.A., Scholz, C.H., and Boatwright, J., 1987, Fractal analysis applied to 219 characteristic segments of the San Andreas Fault: Journal of Geophysical Research: Solid 220 Earth, v. 92, no. B1, p. 331-344, doi: 10.1029/JB092iB01p00331.

221 Bilham, R., and Williams, P., 1985, Sawtooth segmentation and deformation processes on 222 the southern San Andreas fault, California: Geophysical Research Letters, v. 12, no. 9, p. 223 557-560. 
Byerlee, J., 1978, Friction of Rocks, in Rock Friction and Earthquake Prediction, 225 Birkhäuser, Basel, Basel, p. 615-626.

226 Cambonie, T., Klinger, Y., \& Lazarus, V., 2019, Similarities between mode III crack growth

Dooley, T.P., and Schreurs, G., 2012, Analogue modelling of intraplate strike-slip tectonics: A review and new experimental results: Tectonophysics, v. 574-575, no. C, p. 1-71, doi: 10.1016/j.tecto.2012.05.030.

Hatem, A.E., Cooke, M.L., Toeneboehn, K., 2017, Strain localization and evolving kinematic efficiency of initiating strike-slip faults within wet kaolin experiments: Journal of Structural Geology, v. 101, p. 96-108, doi: 10.1016/j.jsg.2017.06.011.

King, G., and Nabelek, J., 1985, Role of fault bends in the initiation and termination of earthquake rupture.: Science, v. 228, no. 4702, p. 984-987, doi: 10.1126/science.228.4702.984.

239 Klinger, Y., 2010, Relation between continental strike-slip earthquake segmentation and thickness of the crust: Journal of Geophysical Research, v. 115, no. B7, p. 1355-19, doi: 10.1029/2009JB006550.

Klinger, Y., Michel, R., and King, G., 2006, Evidence for an earthquake barrier model from Mw 7.8 Kokoxili (Tibet) earthquake slip-distribution: Earth and Planetary Science Letters, v. 242, no. 3-4, p. 354-364, doi: 10.1016/j.epsl.2005.12.003.

Klinger, Y., Okubo, K., Vallage, A., Champenois, J., Delorme, A., Rougier, E., Lei, Z., Knight, E.E., Munjiza, A., Satriano, C., Baize, S., Langridge, R., and Bhat, H.S., 2018, Earthquake Damage Patterns Resolve Complex Rupture Processes: Geophysical Research Letters, v. 45, no. 19, p. 10,279-10,287, doi: 10.1029/2018GL078842.

Klinger, Y., Xu, X., and Tapponnier, P., 2005, High-resolution satellite imagery mapping of the surface rupture and slip distribution of the Mw 7.8, 14 November 2001 Kokoxili earthquake, Kunlun fault, northern Tibet, China: Bulletin of the Seismological Society of America, v. 95, no. 5, p. 19770-11987, doi: 10.1785/0120040233.

Lauer, B., Grandin, R., Klinger, Y., Vallage, A., Jolivet, R., and Delorme, A., 2018, Absence of shallow slip deficit during the Balochistan earthquake (2013, Mw 7.7, Pakistan): insights from SAR and optical-based coseismic slip model: AGU Fall Meeting.

Lozos, J.C., 2016, A case for historic joint rupture of the San Andreas and San Jacinto faults: Science Advances, v. 2, no. 3, p. e1500621-8, doi: 10.1126/sciadv.1500621.

Mandl, G., 1987, Discontinuous fault zones: Journal of Structural Geology, v. 9, no. 1, p. 105-110, doi: 10.1016/0191-8141(87)90047-2.

260 Manighetti, I., Campillo, M., Bouley, S., and Cotton, F., 2007, Earthquake scaling, fault 261 segmentation, and structural maturity: Earth and Planetary Science Letters, v. 253, no. 3262 4, p. 429-438, doi: 10.1016/j.epsl.2006.11.004. 
263 Manighetti, I., Caulet, C., De Barros, L., Perrin, C., Cappa, F., and Gaudemer, Y., 2015, 264 Generic along-strike segmentation of Afar normal faults, East Africa: Implications on fault growth and stress heterogeneity on seismogenic fault planes: Geochemistry, Geophysics, Geosystems, v. 16, no. 2, p. 443-467, doi: 10.1002/2014GC005691.

267

268

269

270

271

Naylor, M.A., Mandl, G.T., and Supesteijn, C., 1986, Fault geometries in basement-induced wrench faulting under different initial stress states: Journal of Structural Geology, v. 8, no. 7, p. 737-752.

Okubo, P.G., and Aki, K., 1987, Fractal geometry in the San Andreas Fault System: Journal of Geophysical Research: Solid Earth, v. 92, no. B1, p. 345-355, doi: 10.1029/JB092iB01p00345.

Richard, P.D., Naylor, M.A., and Koopman, A., 1995, Experimental models of strike-slip tectonics: Petroleum Geoscience, v. 1, no. 1, p. 71-80, doi: 10.1144/petgeo.1.1.71.

Riedel, W., 1929, Zur Mechanik geologischer Brucherscheinungen ein Beitrag zum Problem der Fiederspatten.: Zentbl. Miner. Geol. Palaont. Abt, p. 354-368.

Ritter, M. C., Rosenau, M., \& Oncken, O., 2018, Growing faults in the lab: Insights into the scale dependence of the fault zone evolution process : Tectonics, v. 37 , no. 1, p. 140-153, doi : 10.1016/j.tecto.2017.11.018.

Rosu, A.-M., Pierrot-Deseilligny, M., Delorme, A., Binet, R., and Klinger, Y., 2015, Measurement of ground displacement from optical satellite image correlation using the free open-source software MicMac: ISPRS Journal of Photogrammetry and Remote Sensing, v. 100, no. C, p. 48-59, doi: 10.1016/j.isprsjprs.2014.03.002.

Schwartz, D.P., 2018, Review: Past and Future Fault Rupture Lengths in Seismic Source Characterization-The Long and Short of It: Bulletin of the Seismological Society of America, v. 108, no. 5A, p. 2493-2520, doi: 10.1785/0120160110.

Schwartz, D.P., and Coppersmith, K.J., 1984, Fault behavior and characteristic earthquakes' examples from the Wasatch and San Andreas fault zones : Journal of Geophysical Research, v. 89, no. B7, p. 5681-5698.

Segall, P., and Pollard, D.D., 1980, Mechanics of discontinuous faults: Journal of Geophysical Research: Solid Earth, v. 85, no. B8, p. 4337-4350, doi: 10.1029/JB085iB08p04337.

Tchalenko, J.S., 1970, Similarities between shear zones of different magnitudes: Geological Society of America Bulletin.

Ueta, K., Tani, K., Geology, T.K.E., 2000, Computerized X-ray tomography analysis of three-dimensional fault geometries in basement-induced wrench faulting: Elsevier, v. 56, no. 1-2, p. 197-210, doi: 10.1016/S0013-7952(99)00143-X.

Vallée, M., Landès, M., Shapiro, N.M., and Klinger, Y., 2008, The 14 November 2001 Kokoxili (Tibet) earthquake: High-frequency seismic radiation originating from the transitions between sub-Rayleigh and supershear rupture velocity regimes: Journal of Geophysical Research, v. 113, no. B7, p. 2064-14, doi: 10.1029/2007JB005520. 
Figure 2: Comparison between inter-Riedel distance (S) and sandpack thickness (T) for

Wei, S., Fielding, E., Leprince, S., Sladen, A., Avouac, J.P., Helmberger, D., Hauksson, E., Chu, R., Simons, M., Hudnut, K., Herring, T., and Briggs, R., 2011, Superficial simplicity of the 2010 El Mayor-Cucapah earthquake of Baja California in Mexico: Nature Geoscience, v. 4, no. 9, p. 615-618, doi: 10.1038/ngeo1213.

Wesnousky, S.G., 2006, Predicting the endpoints of earthquake ruptures: Nature, v. 444, no. 7117, p. 358-360, doi: 10.1038/nature05275.

Yang, H., Moresi, L. N., \& Quigley, M., 2020, Fault spacing in continental strike-slip shear zones : Earth and Planetary Science Letters, v. 530, doi : 10.1016/j.epsl.2019.115906.

Zuza, A.V., Yin, A., Lin, J., Sun, M., 2017, Spacing and strength of active continental strikeslip faults: Earth and Planetary Science Letters, v. 457, p. 49-62, doi: 10.1016/j.epsl.2016.09.041.

\section{ACKNOWLEDGEMENTS}

We thank Bertrand Maillot for his insights during experiments and result analyses. M. Cook, H. Yang, and an anonymous reviewer helped improve significantly this manuscript. This work has been partly funded by ANR project Geosmec (ANR-12-BS060016).

\section{FIGURES}

Figure 1: a. Surface rupture map of the 1992 Landers earthquake, California. Segmentation (black lines), according to Klinger (2010). b. Evolutionary scheme of the formation of strike-slip faults, seen from the surface, and a 3D sketch to illustrate the helicoidal-shape of the Riedels. c. Top view of the sandbox, with the measured parameters, S: inter-Riedel distance, L: Riedel length, $\alpha$ : angle between the Riedel and the basement fault.

different frictional and cohesional properties of the sand. a. Pictures of the top of the sandbox 
331 after $\sim 11-12 \mathrm{~mm}$ of displacement for experiments with a 2, 3 and 4 cm-thick sandpack. b., c., 332 d., e. Average inter-Riedel distance (S) per experiment versus sand-pack thickness (T) for 333 Sand 1 (b.); for three different sands with different internal friction (c); for three different 334 basal materials to study the basal friction effect (d); and for two sands with different cohesion 335 (e). Note that for clarity's sake, for Sand 1 on graphics $\mathbf{c}$ and $\mathbf{d}$, we represent the average 336 value by thickness rather than by experiment.

337 Figure 3 : Normalised length of individual fault segments for several continental strike338 slip earthquakes (Klinger, 2010, Lauer et al., 2018) and for individual analogue-fault 339 segments. Sand 1 is shown only for comparison. The length is normalized to inferred 340 seismogenic thickness or sand thickness accordingly. Values of seismogenic crust 341 thicknesses are estimated from the literature (see Supp. Mat.)

342 Figure 4: a. Curl of the incremental displacement field for a $4 \mathrm{~cm}$-thick experiment $(\mathrm{T}=4 \mathrm{~cm})$ 343 at three different stages of the deformation $(\mathrm{d}=7.5 \mathrm{~mm}, \mathrm{~d}=10 \mathrm{~mm}, \mathrm{~d}=13 \mathrm{~mm})$. The curl is 344 derived from the correlation image between two successive pictures of the sandbox surface. It 345 highlights the location of shear. The location of the different active faults (R-shear, S-shear) is 346 highlighted. b. Scheme of the 3D-structures of a strike-slip fault at the crustal scale.

348 Figure 3 : Normalised length of individual fault segments for several continental strike349 slip earthquakes (Klinger, 2010, Lauer et al., 2018) and for individual analogue-fault 350 segments (see Fig. S13 for comparison with sands 1 and 4). The length is normalized to 351 inferred seismogenic thickness or sand thickness accordingly. Values of seismogenic 352 crust thicknesses are estimated from the literature (see Supp. Mat.) 


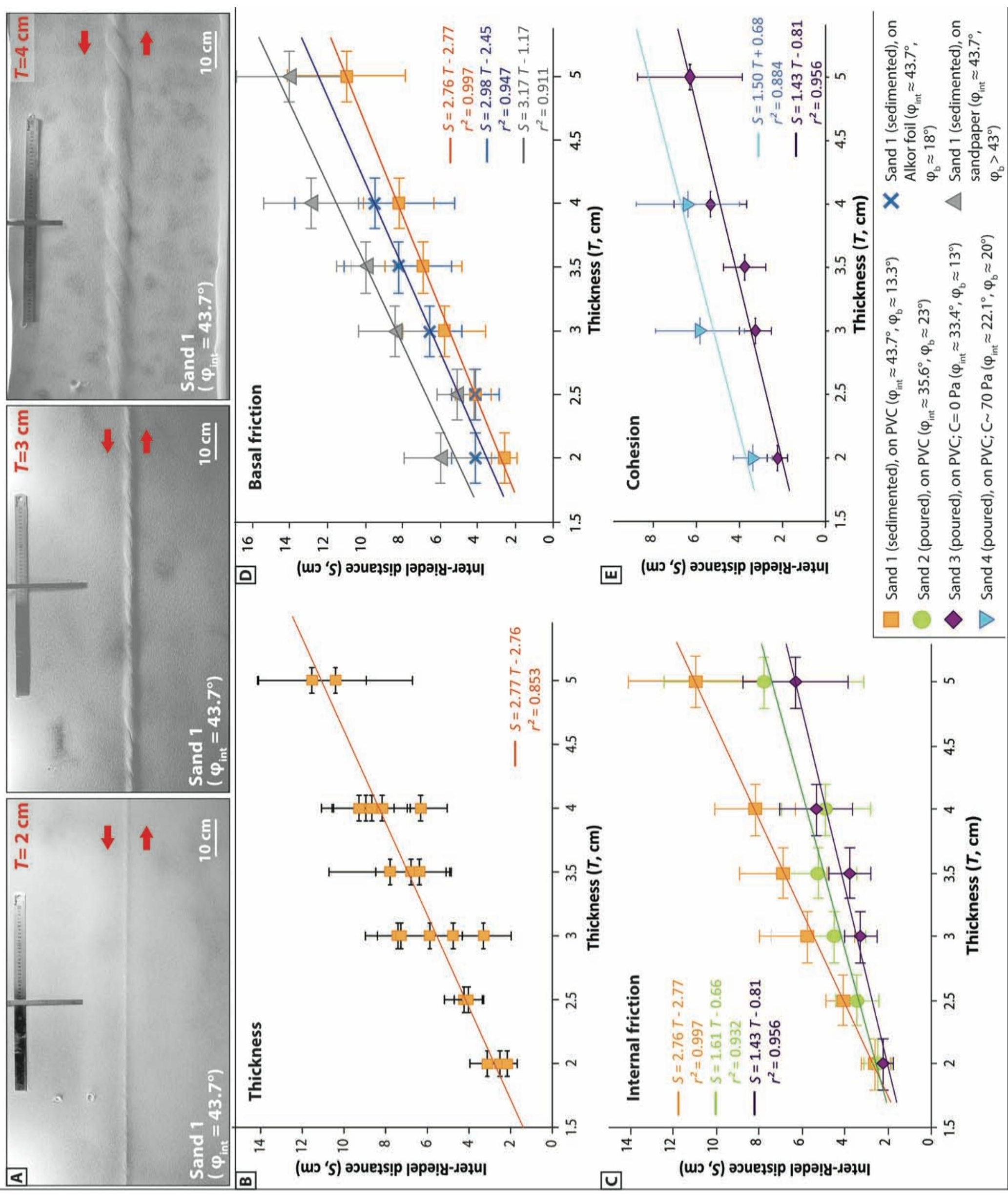




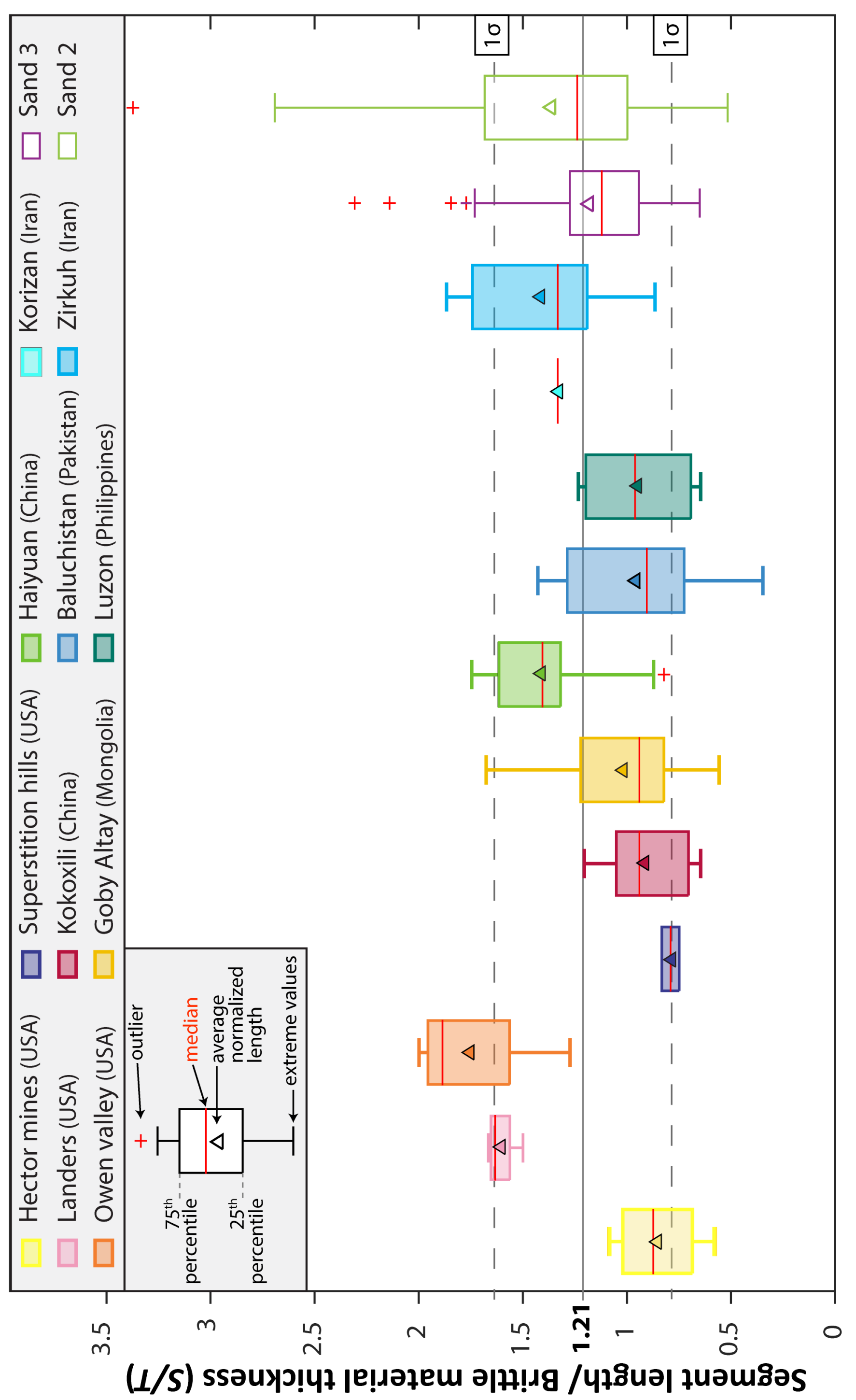




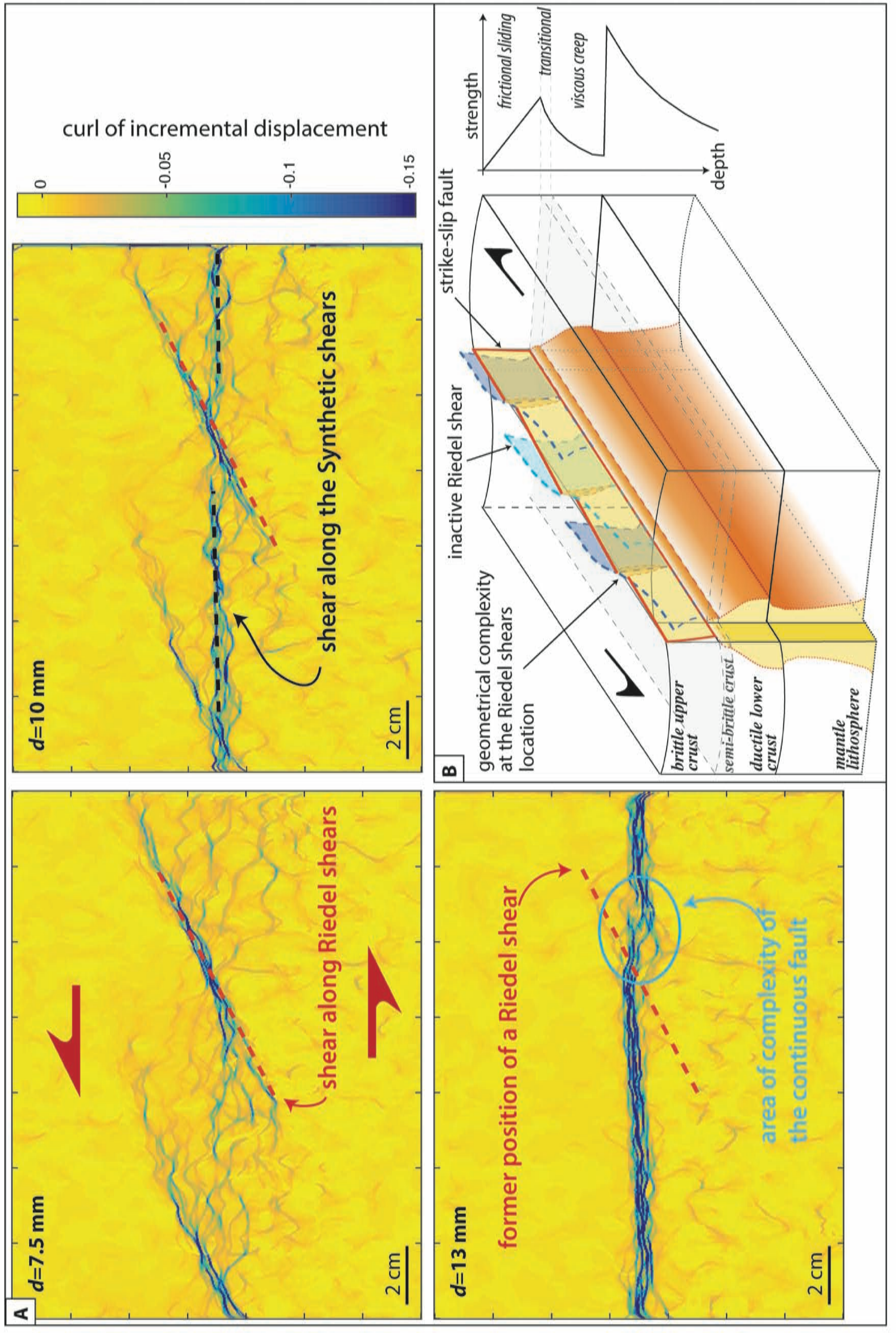

